\title{
Endangered Car Timber species and its management in Odisha
}

\author{
*Mohanty .B., Pattanayak.M.R.
}

\begin{abstract}
Car festival of lord Jagannatha, an worldwide acclaimed festival observed by Hindus is interwoven with not only the culture but also the religious sentiment of the mass. Celebration of this festival requires construction of three new chariots every year. An estimated 400 cubic meter wood from different specified species is required. Once upon a time these wood species were abundantly available in different forest divisions of Odisha. Regular cutting and due other climatic factors the availability of these species become endangered year by year. Even certain species like Phasi become extinct in the nearby divisions. Considering the future demand the state administration developed a plan for protection and just management of existing species and also to plant more species for future use. This management plan was not only to increase no. of species but also it extended area of collection also. Now after One and half decade of intervention the endeavour has stated bearing fruits. There has been a substantial availability of required species and certain species have been saved from extinction.
\end{abstract}

\section{Introduction}

Odisha, a state in the Indian subcontinent, is the abode of many ancient temples as sign of great sculpture. The temple of lord-Jagannatha in Puri and lord Lingaraja in Bhubaneswar depicts the rich tradition of Odishan culture. As per the rituals of these two deities, numerous festivals are observed annually with pump and ceremony. Car festival of lord Jagannatha and lord Lingaraj is one among these festivals which attracts pilgrims from all over the globe and celebrated with grandeur. The Car festival, observed annually, is symbol a socio-cultural attachment of the people. The festival has been interwoven with the sentiment of a large populace within and outside the country.

Traditionally, the chariots (Rathas) for the Car Festival are made of wood. One car is being made for the car festival of lord Lingaraj, while three cars are being made for three deities i.e. lord Jagannatha, Balabhadra and Subhadra for the car festival of Jagannatha. Different parts of the Chariot (Chaka- wheel, Akhaaxil and other body parts) are made from different types of timber.

\section{Availability of Species}

\begin{tabular}{|c|c|c|c|c|}
\hline \multicolumn{5}{|c|}{ Species wise requirement of Car Timber } \\
\hline $\begin{array}{l}\text { S1.N } \\
\text { o. }\end{array}$ & Purpose & Species & $\begin{array}{l}\text { Dimensions } \\
\text { (girthx length) }\end{array}$ & $\begin{array}{l}\text { Logs } \\
\text { (Nos.) }\end{array}$ \\
\hline 1 & Tumba & Phasi & 6'x09' & 022 \\
\hline 2 & Pai & Phasi & 6'x12' & 050 \\
\hline 3 & Gayal & Asan & $3 ’ x 40^{\prime}$ & 312 \\
\hline 4 & Aramundi & Asan \& Dhaura & 3'x12' & 428 \\
\hline 5 & Danda/Akha & Dhaura & 3'x40', & 050 \\
\hline 6 & & Debadaru & $5 ’ \times 10^{\prime}$ & 004 \\
\hline 7 & & Debadaru/mai & $5^{\prime} \times 15^{\prime}$ & 042 \\
\hline 8 & & Moi & $5^{\prime} \times 15^{\prime}$ & 005 \\
\hline 9 & & Moi & 3’x10' & 015 \\
\hline 10 & & Kansa,Simili Planks & $3 ’ \times 10^{\prime}$ & 046 \\
\hline 11 & & Kansa,simili planks & $5^{\prime} \times 15^{\prime}$ & 005 \\
\hline 12 & & Paldhua & $3 ’ \times 10^{\prime}$ & 085 \\
\hline 13 & & Mahalimba & 4'x10 & 020 \\
\hline 14 & & Gambhari & $5^{\prime} \times 12^{\prime}$ & 001 \\
\hline 15 & & Kadamba & $3^{\prime} \times 10^{\prime}$ & 004 \\
\hline 16 & & Kalchua ballahs & 3'x7' & 060 \\
\hline 17 & & Sal & 4'x10'- 5'x10' & 013 \\
\hline
\end{tabular}

planned to extend the supply of car timber to five additional divisions. So that, car timber of different species and desired dimensions would hence forth be available from seven forest divisions to address the immediate need. The additional divisions were Angul, Athagarh, Boudh, Dhenkanal and Athamallik. It was also proposed to incorporate car timber working plan in the working circles of each of the additional divisions. Decision was made to plant seedling of at least one year old, good quality and the field work to be commenced in the year zero. The plantation was to be maintained for a period of six years including the first year of formation.

This led to design some salient aspects of intensive plantations through a scheme for the purpose. The special scheme 'Sri Jagannatha Banaprakala' was launched by the Forest and Environment Department, 
Government of Odisha in the year 1999.

The Project Sri Jagannatha Banaprakala was designed to cover an area of about 2,686 hectares in the aforesaid six forest divisions except Athamallik division. These forest divisions are spread over 7 districts of Odisha. The project area includes temple lands (i.e. lands belonging to the Jagannatha Temple Administration), Govt. Revenue Wastelands and Reserve Forests. Land earmarked for intensive plantation purpose was identified in consultation with the temple Administrations/Revenue authorities. These lands have been considered suitable for raising plantations of the desired species. The identified lands actually available for the proposed plantations were free from any encroachment / encumbrance. Jagannatha Banprakalpa under VSS in Nayagarh District

\begin{tabular}{|c|c|c|c|c|c|c|}
\hline Villages & Land kisam & $\begin{array}{l}\text { Khata } \\
\text { no. }\end{array}$ & Plot no. & Area(acre) & uitability (Ha.) & Remarks \\
\hline Pathara & Patra jungle & - & $1178,1180,1190$ & $16.50,18.90,9.62$ & 12.00 & $\begin{array}{l}\text { Revenue } \\
\text { Dept. }\end{array}$ \\
\hline Kendupalli & -do- & - & $14,24,21,25,90$ & 133.87 & 28.00 & do \\
\hline $\begin{array}{l}\text { Ramachandra } \\
\text { Prasad }\end{array}$ & Jungle & 172 & $166,164,252$ & 19.03 & 6.00 & do \\
\hline Pokharigochha & -do & - & - & 45.00 & 18.00 & do \\
\hline Banigochha & -do- & - & - & 100.00 & 34.00 & do \\
\hline Kalsakhaman & -do- & - & & 60.00 & 20.00 & do \\
\hline $\begin{array}{l}\text { Phalpaju } \\
\text { Nuagaon }\end{array}$ & $\begin{array}{l}\text { Jungle } \\
\text { Mela/Village } \\
\text { forest }\end{array}$ & - & $78.52,51,47,50$ & 125.81 & 50.00 & do \\
\hline Wallipur & -do- & - & - & 25.00 & 10.00 & do \\
\hline Manivadra & -do- & - & & 5.00 & 2.00 & do \\
\hline Mahipur & $\begin{array}{l}\text { Gramya } \\
\text { Jungle }\end{array}$ & 1239 & 2050,2051 & 31.63 & 12.00 & do \\
\hline
\end{tabular}

Source: Scheme on plantation for making the timber requirement of chariots for car festival, Puri

\begin{tabular}{|c|c|c|c|c|c|c|}
\hline \multicolumn{7}{|c|}{ Land under Sri Jagannatha Banaprakalpa } \\
\hline SI.No. & Division & District & $\begin{array}{l}\text { Temple } \\
\text { Area(Ha) }\end{array}$ & $\begin{array}{l}\text { Revenue } \\
\text { Area(Ha) }\end{array}$ & $\begin{array}{l}\text { Forest } \\
\text { area }(\mathrm{Ha})\end{array}$ & $\begin{array}{l}\text { Total } \\
\text { area }(\text { Ha) }\end{array}$ \\
\hline 1 & Angul & Angul & - & 015.00 & 385.00 & 400.00 \\
\hline 2 & Atagarh & Cuttack & - & 500.00 & - & 500.00 \\
\hline 3 & Boudh & Boudh & - & 113.00 & 250.00 & 363.00 \\
\hline 4 & Dhenkanal & Dhenkanal & - & 140.00 & 100.00 & 240.00 \\
\hline 5 & Nayagarh & Nayagarh & - & 335.00 & 065.00 & 400.00 \\
\hline 6 & Puri & Khurda & 283.00 & - & 100.00 & 383.00 \\
\hline 7 & Puri & Puri & N.A & - & - & 400.00 \\
\hline Total & & & 283.00 & 1103.00 & 900.00 & 2686.00 \\
\hline
\end{tabular}

Gambhari (Gnelinab arboria), Moi (Lannea grandis), Kadamba (Anthocephalus kadamba), and Debadaru (Polyaithia longifolia). An estimated 400 cubic meters of various species are required annually to construct these cars of lord Jagannatha. Section 4(1) of the Puri Car festival code 1983, entrusts upon the Government of Odisha, Forest and Environment Department to supply these required timber for construction of chariots free of cost every year. The said code also mandates the Divisional Forest Officers (DFOs) of Puri \& Nayagarh forest divisions to supply timber of desired dimensions and species to Puri temple Administrations \& Lingaraj temple Administration.

Given the socio-cultural importance of these car festivals in Odisha \& its celebration as the "state festivals", Forest and Environment Department, Government of Odisha is required to fulfill the need of timber for the car festivals. In past, the supply of these timber was very much unplanned and mostly adhoc in nature. Forest officials of Puri and Nayagarh forest divisions were indentifying trees of desired dimensions and species from all over the forest. Then the marked trees were culled. In past, hardly any attention was given for regeneration of species. There was no scientific estimation of the availability of suitable species to meet the future demand. Gradually, the scarcity of the timber was felt as the species required for car timber was subjected to endangered in these forest divisions. The major reasons were intense biotic interference (i.e. illicit felling, grazing and fires), increasing urbanization of the regions \& other climatic factors.

Consequently, the Divisional Forest Officers of Nayagarh and Puri faced considerable difficulties in supplying timbers of desired dimensions, quality and species due to continued degradation of these forests. In particular, certain species like Phasi, which occur in specific sites in riparian zones got considerably reduced. 
In these circumstances, it was felt that sustained supply of car timbers might suffer unless systematic efforts are made to address this problem.

\section{Strategy adopted}

Regular cutting down of timber for construction of Chariot for Car Festival resulted in endangering these species. The availability of required trees dwindled gradually. It was also decided that the concerned Divisional Forest Officers will be responsible for the successful formation, establishment and management of these endangered species. To address these problems, a two pronged strategy was conceptualized. One is an intensive plantation scheme for all species, except Sal. However, it was also considered that the proposed intensive plantations would not able to meet the immediate requirements of car timber. Hence, as a second option, it was

\section{Role of Community}

Over a period of time, local community played a vital role in protecting and managing this forest. Vana Samrakhyana Samities (VSSs) were formed and guided under the principles of Joint Forest Management. These samities are active in maintaining such species. VSS members are guarding the plantation site round the clock. As a religious sentiment is attached to it, the people are taking special interest to make this project successful. Though the project was initially conceived and designed by the government, now it has been more recognised as a peoples' project.

\section{Concluding remark}

As car festival of lord Jagannatha is deeply connected with the religious feelings of the people and requires a fixed amount of wood of diversified species every year, a detailed planning for sustainable availability of the same was of utmost priority. Sri Jagannatha Bana Prakalpa is a step in time considering the continuous need and endangered species. Local people have also come forward to protect, manage and conserve the species planted in the project in order to satisfy the future need. This would undoubtedly a march in time.

\section{References}

[1]. Community Forest Mangement in Orissa, Community Forestry, April 2005- Barna Baibhaba Panda

[2]. Working plan of Shri Jagannath Bana Prakalapa-1999- Forest and enviroment Department, govt. of Odisha

[3]. The present status of Forest and Forest Activities in Orissa- Orissa Review- August 1990-91- Ajit Bhartuar

[4]. Car timber (Overlapping) working circle, Chapter-10,Working plan2007-08 to 2016-17- Nayagarh District

[5]. Effect of Joint Forest Management programme on community forest management in Odisha - 1998- Rekha Panigrahy and Y. Girirao

[6]. Effective local management of forest- Learning from self initiated management organization in India- a case of community forest protection Nayagarh District- Vasundhara

[7]. Report on difficulties of JFM /CFM affecting forest dependent communities in Orissa- working paper-2006- Nabaghana Ojha

[8]. Study of JFM - Report submitted to Ministry of Environment and Forest, Govt. of India 